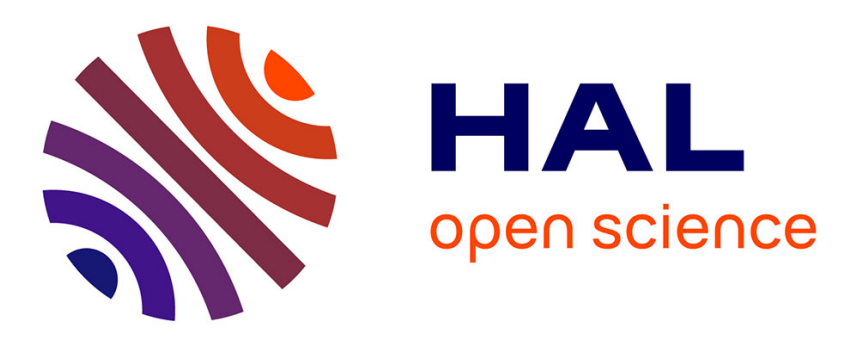

\title{
Initiating collective action for the management of deep confined aquifer systems: application of a participatory scenario approach in France
}

\author{
Josselin Rouillard, Noémie Neverre, Jean-Daniel Rinaudo
}

\section{To cite this version:}

Josselin Rouillard, Noémie Neverre, Jean-Daniel Rinaudo. Initiating collective action for the management of deep confined aquifer systems: application of a participatory scenario approach in France. Hydrogeology Journal, 2021, 10.1007/s10040-021-02420-1 . hal-03431511

\section{HAL Id: hal-03431511 https://hal-brgm.archives-ouvertes.fr/hal-03431511}

Submitted on 2 Dec 2021

HAL is a multi-disciplinary open access archive for the deposit and dissemination of scientific research documents, whether they are published or not. The documents may come from teaching and research institutions in France or abroad, or from public or private research centers.
L'archive ouverte pluridisciplinaire HAL, est destinée au dépôt et à la diffusion de documents scientifiques de niveau recherche, publiés ou non, émanant des établissements d'enseignement et de recherche français ou étrangers, des laboratoires publics ou privés. 
Initiating collective action for the management of deep confined aquifer systems: application of a participatory scenario approach in France

Josselin Rouillard ${ }^{123} *$, Noémie Neverre ${ }^{23}$, Jean-Daniel Rinaudo ${ }^{23}$

1. Ecologic Institute, Pfalzburger Str. 43-44, 10717 Berlin, Germany. Email: josselin.rouillard@ecologic.eu

2. BRGM, Univ Montpellier, Montpellier, France

3. G-Eau, UMR 183, INRAE, CIRAD, IRD, AgroParisTech, Supagro, BRGM, Montpellier, France

*Corresponding author

Josselin Rouillard ORCID : 0000-0002-1070-5325

Noémie Neverre ORCID : 0000-0002-7291-0578

Jean-Daniel Rinaudo ORCID: 0000-0001-8539-574X

\section{Abstract}

Large deep confined aquifer systems play a crucial role for water and food security and the economic development of rural areas. However, there are few cases, worldwide, of integrated management and governance of such groundwater resources. This paper first investigates factors that hamper stakeholders' involvement in groundwater management, in particular deep confined aquifer systems that extend over a large regional area. It then shows how participatory scenario analysis can be used to trigger collective action by regional actors. The paper relies on the case study of a large confined aquifer in South West France impacted by multiple pressures from the drinking water, energy, agriculture, and health sectors. It is shown how participatory scenario analysis contributed to building a shared understanding of the resource amongst regional actors and generated a collective view of the main groundwater management challenges. Results also suggest that engaging stakeholders in futures thinking at the beginning of the participatory process is a powerful approach to generating a commitment for collective action on groundwater.

\section{Keywords}

Common pool resources; Socio-economic aspects; Participatory Methods; Future studies; France 
Confined aquifers in particular represent a strategic resource in many parts of the world given their natural protection from human pollution and their potential role as buffers against the impact of climate extremes. Where surface water systems and shallow aquifers have become over-allocated or polluted, deep confined aquifers still provide a valuable alternative source of water. The strategic importance of these deep confined resources has been recognised in different regional contexts, such as the Great Artesian Basin in Australia (Robertson, 2020), the Nubian and Sahara Aquifer System (Nijsten et al 2018) or the Guarani aquifer system in Brazil and neighbouring countries (Sindico et al 2018). Yet, successful examples of deep-aquifer sustainable management are few, and concern is growing worldwide on the emerging global groundwater crisis (Famiglietti 2014).

The integrated management and governance of deep, confined aquifer systems faces several challenges (Jakeman et al 2016; Lapuyade et al 2020). Detailed mapping and monitoring is difficult to achieve due to their depth and complex hydrogeology. The boundaries of confined aquifers, where known, rarely match those of surface water basins around which water management actors usually manage water resources. Furthermore, depletion from deep aquifers does not create immediate visible impacts, unlike with shallow aquifers where depletion usually affects dependent ecosystems, triggering a quick response from social groups who depend on those ecosystems. Due to all these factors, public and private actors concerned with confined aquifers may not necessarily realise the risks resulting from the overexploitation of the resource. As a result, regulators, politicians, economic users and their representatives may have a low willingness to invest time and resources in the development of restrictive groundwater management plans.

To engage stakeholders in groundwater management, the most classical approach assumes that they must be trained to acquire basic scientific and technical knowledge required to understand the issues at stake and develop their own opinions (McClurg and Sudman 2000; Aureli et al 2008; Re and Misstear 2017). However, this learning process requires a significant investment that the actors will only agree to make if the problem becomes "higher priority" than others with which it is in competition. To do so, they must be convinced of the usefulness and potential impact of their participation. This requires an awareness (1) of the risks associated with inaction, (2) of their ability to influence the future of the system, and (3) of the existence of levers to change the course of events. The approach defended by the authors of this article is that participatory scenario analysis, focusing on the long term evolution of the resource and its uses, is an approach that can arouse curiosity and interest in groundwater issues and, ultimately, facilitate the engagement of stakeholders in collective management.

This article tests the use of participatory scenario analysis to make groundwater, in particular deep aquifers, "visible" (Lopez-Gunn 2009) to stakeholders and initiate their integrated management. Stakeholders involved include users from different sectors (agriculture, drinking water supply, spa industry, energy), representatives from local governments and state agencies (regulators). The case study, in South West France, relates to the protection of three connected large-scale, deep confined aquifers, that are strategic for drinking water supply given their high quality water and geographic extension. The area is characterised by a highly heterogeneous hydrogeology impacted by multiple pressures from the drinking water, energy, and agriculture sectors, and the spa industry. The paper presents an inter-disciplinary methodology based on pre-defined scenarios debated in workshops for engaging actors and creating a shared vision of the strategic importance of the sustainable management of these deep aquifers. 
The article first analyses the challenges in engaging actors in groundwater management, focusing on deep, confined aquifers, and reviews the role that participatory scenario analysis can play in initiating collective action for their management. It then presents in detail how participatory scenario analysis was used in the French case study, including the steps in creating a shared knowledge base and engaging users in identifying common principles for the future management of the aquifer. It concludes with the potential for such an approach to be applied more widely for sustainable management.

\section{Engaging actors in collaborative groundwater management}

There is a consensus among policy makers, practitioners and scholars that users and other actors having a stake in groundwater management should be closely associated to the resource monitoring, the discussion of scenarios, the definition of management targets and interventions, the implementation and evaluation of action plans and their adaptation (Barthel et al 2017). This section analyses the factors that may impede the emergence of this collaborative governance, focussing on confined aquifers. It then shows how scenario planning can facilitate the emergence of collaborative governance.

\subsection{What are the challenges?}

Experienced basin managers commonly agree that it is more difficult to involve stakeholders in the management of deep confined aquifers than in surface water resources or shallow aquifers. Several challenges specifically related to confined groundwater resources are put forward.

The first challenge is related to the lack of knowledge both stakeholders and scientists have on deep confined aquifers. Because they are complex objects, located at greater depth, stakeholders are highly dependent on experts and their scientific tools (piezometric networks, geological profiles, mathematical models) to understand their dynamics. This complexity is linked to the threedimensional geometry of groundwater bodies, the possibility of interconnection of several reservoirs in multilayer aquifers, the phenomenon of captive flow (under pressure), and to the particular ways in which groundwater interacts with surface waters. These characteristics are not intuitively understood, and their communication requires more effort than for surface water and shallow aquifers, and also the use of specific visualisation tools (Baldwin et al 2012; Richard-Ferroudji and Lassaube 2020).

The challenge also lies in clearly defining uncertainties and acknowledging knowledge gaps (Foster and Chilton, 2018). While stakeholders exploiting wells (public water utilities, farmers, industries) may have a good vision of how the aquifer reacts locally, they rarely understand groundwater dynamics at a regional level. Scientific hydrogeological knowledge remains more fragmentary than for surface water or shallow aquifers, as hydrogeologists only have a partial 3D view of the reservoir through scarce deep drilling logs, piezometers and pumping tests. This is contrasting with shallow aquifers and surface water bodies which are more easily accessible for observation. Significant uncertainties may thus exist regarding the spatial extension of deep aquifers, their temporal dynamics and the size of resource stock. It is also difficult to assert with certainty the spatial flow dynamics, the interactions between extraction points and the impact of extraction on total aquifer storage.

The second challenge is the lack of public awareness of groundwater issues (Suvedi et al 2000; Dickerson et al 2007; Arthurs et al, 2018; laDue et al 2021). While numerous societal groups feel 
concerned by surface water management, deep aquifer systems, are largely unknown to the public. It is therefore less likely that political leaders will take up the issue and drive a consultative process.

The third challenge lies in the lack of a sense of interdependence between groundwater users. Due to the spatial extension of the confined aquifer, its uncertain (and often complex) geometry, users of deep confined aquifers do not necessarily know that they are part of the same hydrogeological system. Unlike in river basins, where the link between upstream and downstream use is directly observable, they may not perceive the physical reality of their interdependence. In addition, stakeholders and users that should be involved in the management of large, deep and confined aquifer systems have generally not had previous opportunities to collaborate, as water management is typically organised along river basin boundaries, which rarely coincide with those of deep confined aquifer. For all these reasons, they rarely have the feeling of belonging to a community of users. Building such sense of belonging requires time, political will and resources - which may be lacking (Duda, 2018; Molle and Lopez-Gunn, 2018) until stakeholders realize they share a common destiny with respect to the groundwater resource.

The fourth challenge relates to the need to take a long-term perspective when engaging in groundwater management. The evolution of groundwater status (especially in captive aquifers) is often marked by great inertia. Aquifer recharge, transfer of pollutants, salt-water intrusion in coastal areas, and land subsidence caused by overexploitation, are all phenomena that evolve slowly. Several decades may pass before observing the effects of actions implemented today to protect the resource. This lack of visible results in the short term, while the economic and political costs of action are immediate, can represent a brake on the commitment of stakeholders.

The fifth and final challenge is that stakeholders often lack the required data, scientific skills and tools (including models) to forecast the long term consequences of confined aquifer mismanagement. This knowledge gap can lead to the expression of views challenging the seriousness of the problem or its probability of occurrence. Such views may be based on the existence of scientific controversies, it may aim to protect economic interests, or it may be the expression of beliefs rather than scientific evidence (see Budds 2009 for an illustrative case in Chile). As time passes, difficult decisions are postponed without stakeholders being fully aware of the cost of inaction.

Given these numerous barriers, collective action to protect groundwater bodies, especially deep and captive aquifers, has received less attention than for surface water bodies. In France for instance, only 8 of the 181 local water management plans implemented or being developed focus on groundwater (Rinaudo et al 2020). The next section revisits key determinants of collective action and analyses how participatory scenario analysis can contribute to engage actors in groundwater management.

\subsection{How can participatory scenario analysis help?}

Ostrom's (1990) landmark work has examined the determinants explaining enduring collective action in natural resource management. Several of her cases focused on local groundwater management in California (USA), building on her own work and later analysis by Bloomquist (1992). Two factors in particular appear basic ingredients to initiate collective action. First, actors must agree on clear boundaries on the resource, its characteristics and the web of actors exploiting and benefiting from its exploitation. A rich literature has since examined these preconditions for local collective action on groundwater (López-Gunn 2009; Rica et al 2012; Skurray 2015; Richard-Ferroudji and Lassaube 2020). These studies highlight the role of enhanced information on groundwater variability and dynamics, careful identification of all potential users, and building a shared knowledge base. 
Second, actors must find that the benefits of collective management outweigh the cost of not working together; in other words actors must understand the risks of failing to implement jointly agreed rules so as to agree to pay the transaction costs involved in starting collective action (Ostrom 1990). This requires creating an understanding of the interdependence between actors (Skurray 2015) and disproportionate cost of acting alone (Rica et al. 2012), as well as creating bonding and bridging social capital formed through shared values and norms, and enhanced interconnections (Lopez-Gunn 2012).

Participatory scenarios analysis provides a structured framework for initiating collective action. Scenarios are narratives describing what the future might hold (Reed et al. 2013). Scenarios can support actors in envisioning undesirable situations that everyone wishes to avoid, imagining more desirable futures, and exploring possible transitions towards these futures. Scenarios do not aim to predict or forecast the future. They describe internally coherent, contrasting developments that may integrate break-up with current trends, leading to situations that can be very different from the present or business as usual scenarios. Scenarios must be sufficiently different in order to foster creativity between scenario workshop participants. Their main aim is not about finding the best solution, but about providing a platform to reflect on the possible evolution of the social-ecological system studied (Schneider and Rist 2013).

Scenario workshops can be used as a platform for social actors to construct new relationships or enhance existing ones, encourage creative discussion on complex social-ecological systems dynamics and build participants capacity in systematic and strategic thinking (Johnson et al. 2012). The focus on long timescales (eg. what happens in $20+$ years) can help create a disconnection with immediate decisions to be taken and thereby reduce strategic behaviour because interests do not need to be protected in the short term. The focus is on sharing knowledge, perspectives and worldviews in order to expand one's mental model and encourage the creation of novel ideas to support decisionmaking.

While it is illusory to imagine that politics can be removed, especially in controversial or conflictive issues, scenario workshops can contribute to negotiations over the norms, rules and power relations governing the use of natural resources (Schneider and Rist 2013). Hence, scenarios can contribute to developing "transformation" knowledge by supporting the mapping out of pathways, strategies, policies, programmes, and practices leading to desirable future.

Schneider and Rist (2013) argue that different types of scenario achieve different changes to actors' knowledge. Normative scenarios, where each envisioned future maps against different tangible goals, develop target knowledge (desirable goals). Explorative scenarios, where futures maps with different dynamics, develop systemic knowledge on current conditions, the relationships between system components and their possible evolution. In their study, Schneider and Rist (2013) first developed normative scenarios then explorative scenarios on sustainable regional development and related water governance.

\section{An application on a large regional, deep and captive aquifer in south west France}

\subsection{The Adour-Basin}

The regional deep confined aquifers under study are located in the Adour basin, in southwest France, and extend across two regions and four counties (départements) (Figure 1). The groundwater resource is a multilayer aquifer system situated in deep sedimentary layers formed during the 
Cretaceous, the Paleocene and the Eocene. The most productive and most used of these aquifers is the Sub-Molassic Sands (SMS) aquifer (Eocene layer) whose thousands-year-old water is of pristine quality. The aquifer system, partly recharged in the foothills of the Pyrenees Mountains, is generally located at a depth of several hundred meters, which protects it from surface pollution sources (see also Douez, 2007; Wuilleumier, 2019; BRGM, 2021).

The sedimentary layers have undergone important geological deformations (faults, folds, etc.) with the uplift of the mountain range 50 million years ago. Part of the complexity of the system is due to this very disturbed geology, in particular:

- In certain locations, the deformations have brought the deep layers close to the surface (emergence areas). Hence, in these areas the confined aquifers are vulnerable to percolation of polluted water from surface land uses.

- In the Eocene layer, two deep anticlinal folds form bell-like structures with an impermeable molassic ceiling. The gas industry uses these geological structures as storage sites. Gas is injected in the anticline in summer (during low demand period) and recovered in winter when energy demand increases. The two gas storage sites in the SMS aquifer are strategic to France's gas supply; they represent $24 \%$ of the country's underground storage capacity (Terega, 2021).

- The existence of faults enables the upwelling of high-quality warm water from the deep aquifers, resulting in hot springs that have been exploited since Roman times and now support an important spa industry.

- The different aquifer layers are not always isolated from each other. The SMS aquifer interacts with the underlying Paleocene and Cretaceous aquifers, in areas where the layers come into contact. The existence of water flows between the three aquifer layers implies that the three should be managed together, increasing the complexity. 


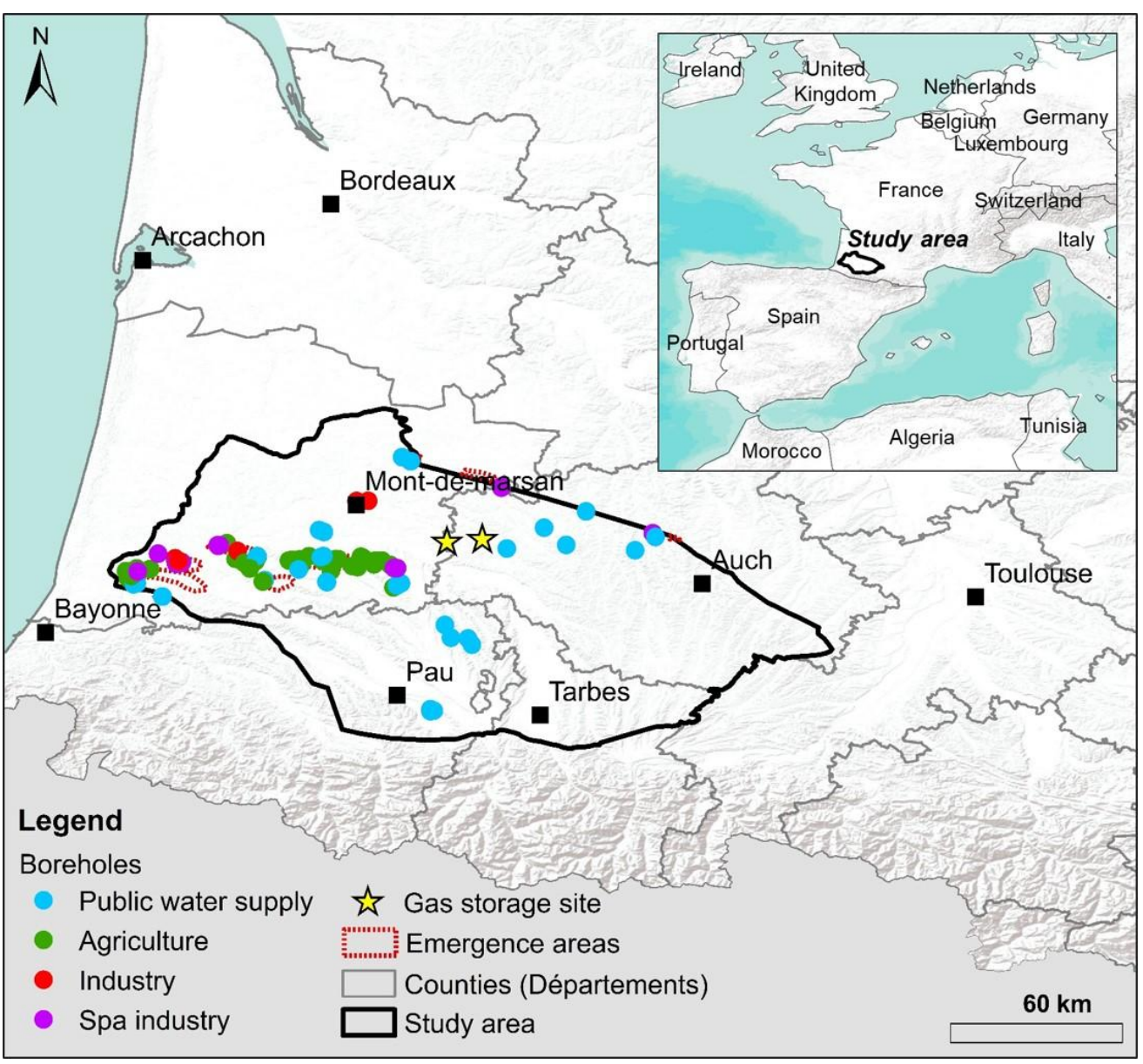

232 Fig. 1. Study area and boreholes pumping in the deep aquifers of South West France

\subsection{Key management issues}

This aquifer system has been increasingly exploited since the 1980s. Today, about 24 million cubic meters are abstracted yearly for drinking water supply (70\% of total extraction), the spa industry $(13 \%)$, agricultural use (11\%), and industrial uses including bottled water and geothermal heating (6\%). The deep aquifers are strategic for each of these uses in different ways (Neverre et al 2020):

- Drinking water extraction from the deep aquifers can be strategic for many communities, as surface sources are unreliable, due to pollution and drought risk. Overall, more than 70,000 inhabitants are entirely dependent on the deep aquifers for public water supply.

- The spa industry represents an essential economic activity for local rural communities, bringing up to 90,500 clients every year, representing 1.5 million overnight stays, a total turnover of 223 million $€$ and creating about 3,200 direct and indirect jobs in the whole study area.

- Groundwater from the deep aquifers is also extracted for the irrigation of about 2000 ha of agricultural land, in areas where surface low flows in the dry season are severe.

The different users of the aquifers interact in many ways, causing several management issues:

- Due to increased pumping, piezometric levels of the SMS aquifer have dropped by $60 \mathrm{~cm}$ on average every year in the last 20 years, with no sign of stabilization despite a ban by the state on new borehole drilling. As a result, the SMS aquifer has been declared to be in bad 
quantitative status under the EU Water Framework Directive. Reducing groundwater

\subsection{Methodology}

\subsubsection{Rationale} extraction would be required to ensure its sustainability. A temporary ban on drilling was imposed by the State in 2010 but use by existing wells is not regulated (no restrictions in place) as such rules have to be developed together with users as part of a comprehensive management plan (justification of the current study)

- The succession of gas injection (summer) and extraction (winter) from the storage sites results in seasonal piezometric variations of up to $80 \mathrm{~m}$ and consequentially impacts pumping installations of other uses in particular drinking water supply and the spa industry.

- In areas where the confined aquifers rise close to the surface, excess pumping and reduced pressure in the aquifers may locally generate an inflow of poor quality water from polluted overlying shallower aquifers and surface waters. A number of drinking water boreholes were impacted (a number of which were abandoned) as well as the spa industry (forced to drill deeper wells as existing ones were affected by contamination). Increasing pollutant concentrations may require a relocation of wells away from emergence areas, or deeper where water is of better quality but less accessible, if at all.

A number of sophisticated participatory scenario analysis methods were developed to co-construct visions of possible developments (Van der Heijden et al 2002). Their major disadvantage is that they require a high level of time involvement from the participants, which is impossible in the context of confined aquifers (very limited initial interest of stakeholders).

The approach presented in this paper aims at solving that problem. It consists in developing narrative scenarios based on information collected through bilateral interviews, and debating them in half-day workshops (Rinaudo et al 2012; 2013). They are written in the form of fictitious press articles, assuming that the use of narratives makes it easier for stakeholders to grasp the issues at stake and to appropriate knowledge (Richter et al. 2009). "Man is an animal of stories" (Jouvenel 2004) and we are most likely to engage actors in a participatory approach by taking a step away from the cold scientific reality and moving towards fiction. In the approach described here, the scenarios blend explorative and normative elements with the objective of developing system knowledge on the dynamics of the confined aquifer, the interdependence of local actors extracting water and the different response strategies to reduce extraction and protect the resource in the long term. Hence, the scenarios usually include (i) some elements that reflect people's preference on futures and (ii) the measures for reaching that future.

The semi-directive interviews with the actors in the area helped to formulate the main scenario hypotheses. The main challenge lies in constructing scenarios that can be considered realistic by participants, while incorporating enough transformative assumptions to force them to think "outside the box". The time horizon of the scenarios must be far enough so that major structural changes could take place.

Scenarios were debated with several objectives:

- To raise awareness among stakeholders of the possible consequences of inaction and the power that participation gives them to influence the course of events. 
- To create a sense of community: participants are allowed to venture into uncharted territory together, starting out on an equal footing in terms of their knowledge of groundwater. It facilitates the expression of deep and personal convictions (aspirations, values), as the distant time horizon makes it possible to distance oneself from institutional positions related to defending their immediate interests. In such way, the participatory scenario exercise allows for the creation of links between individuals who engage together in an exploration of the future.

- To demystify the complexity of the groundwater system and to give participants confidence in their ability to acquire the knowledge necessary for informed decision-making.

\subsubsection{Implementation}

The methodology was implemented in three steps, as shown in Figure 2. The first step involved a first workshop in which participants debated a synthesis of existing scientific and local knowledge on the hydrogeology of these aquifers, the economic significance of the aquifer for water uses, key management issues, potential management actions, key drivers of change, and expected evolutions in the next decade(s) (See Institution Adour, 2021). The aim was to raise actors' awareness of their interdependency via the deep aquifers.

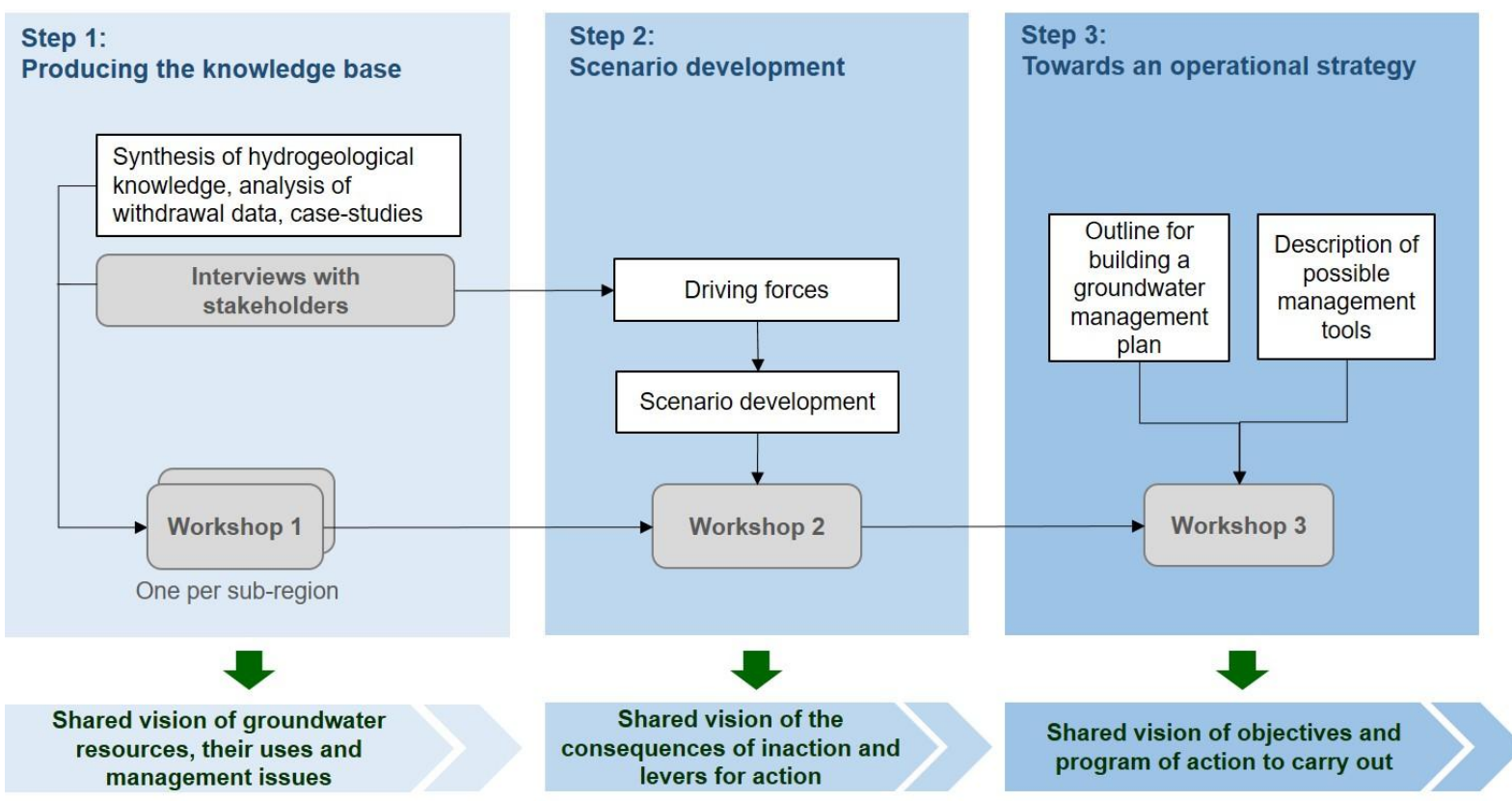

Fig. 2. Overview of the three-stage approach 
Table 1. Number of stakeholders from the different sectors engaged in the participatory approach

\begin{tabular}{|c|c|c|c|c|}
\hline Sector & $\begin{array}{l}\text { Interviews (April- } \\
\text { December 2018) }\end{array}$ & $\begin{array}{c}\text { Workshop } \\
1 \\
\text { (December } \\
\text { 2018) } \\
\end{array}$ & $\begin{array}{l}\text { Workshop } \\
2 \text { (April } \\
\text { 2019) }\end{array}$ & $\begin{array}{l}\text { Workshop } \\
3 \text { (October } \\
\text { 2019) }\end{array}$ \\
\hline $\begin{array}{l}\text { Public water supply utilities } \\
\text { (engineers \& elected board } \\
\text { members) }\end{array}$ & 4 & 11 & 11 & 9 \\
\hline $\begin{array}{l}\text { Agriculture (professional } \\
\text { organisations, associations of water } \\
\text { agricultural users) }\end{array}$ & 6 & 4 & 2 & 2 \\
\hline Spa industry (private group) & 1 & 2 & 3 & 3 \\
\hline Geothermal energy & 2 & 1 & 2 & 1 \\
\hline Gas storage company (Terega) & 1 & 1 & - & 1 \\
\hline $\begin{array}{l}\text { Adour river basin management } \\
\text { authority (AEAG) }\end{array}$ & 1 & 3 & 3 & 3 \\
\hline $\begin{array}{l}\text { County councils (départements): } \\
\text { engineers \& elected council } \\
\text { members) }\end{array}$ & 2 & 2 & 1 & 6 \\
\hline $\begin{array}{l}\text { Adour Garonne River basin District } \\
\text { Agency }\end{array}$ & 1 & 1 & 1 & 3 \\
\hline $\begin{array}{l}\text { Environmental Regional Government } \\
\text { Agency (DREAL) }\end{array}$ & - & - & 2 & 1 \\
\hline $\begin{array}{l}\text { Health Regional Government Agency } \\
\text { (ARS) }\end{array}$ & - & - & 1 & - \\
\hline $\begin{array}{l}\text { Government agency in charge of } \\
\text { land-use planning (DDTM) }\end{array}$ & - & - & 1 & - \\
\hline Total & 18 & 25 & 27 & 29 \\
\hline
\end{tabular}

The second step involved a second workshop in which two narrative scenarios of the future were developed and debated. The first related to a baseline scenario where no action is taken ("Iaisserfaire") with a 2040 timeline, which was coherent with the observed trends and deemed near enough to be relevant for management planning. The "laisser-faire" scenario was presented in the form of three fictional press releases, for which the story is summarized in Figure 3. 


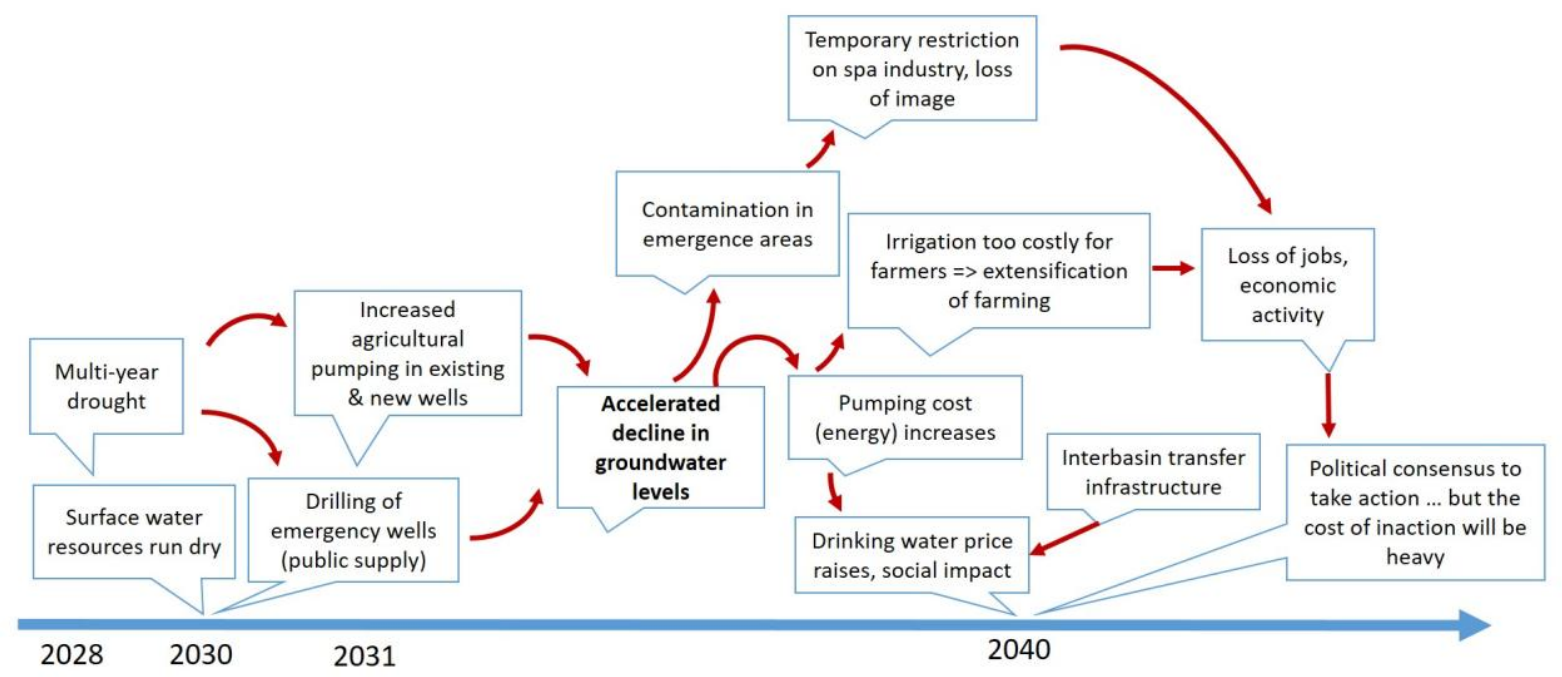

333 Fig. 3. Main assumptions of the "laisser-faire" scenario

335 The newspaper fictional articles (see Neverre et al 2020) take the reader into a situation of multi-year 336 drought which dries up or affects the quality of most surface resources, leading to the urgent 337 creation of deep wells. Where deep aquifers are more accessible, agricultural users also rely on these 338 aquifers to increase their security of supply. While the deep aquifers save the region from drought in 339 the short term, the increase in withdrawals precipitates the drop in piezometric water levels. Ten 340 years later, the pumps of many boreholes risk being dewatered, thermal resources are affected, 341 leading to the temporary closure of some spa resorts, and gas storage activities are compromised. In 342 that narrative scenario, elected representatives finally call for action in 2040, although part of the 343 damage has already taken place.

344 A second scenario was then debated, in which decision makers would have been more pro-active. 345 The scenario was presented as a fictitious roadmap comprising of several measures to regulate 346 withdrawals and protect the aquifers from surface pollution (Figure 4). The measures are described 347 in detail to enable participants to understand the regulatory, economic and institutional levers that 348 can be used to influence the course of events. They are implemented from 2030. 


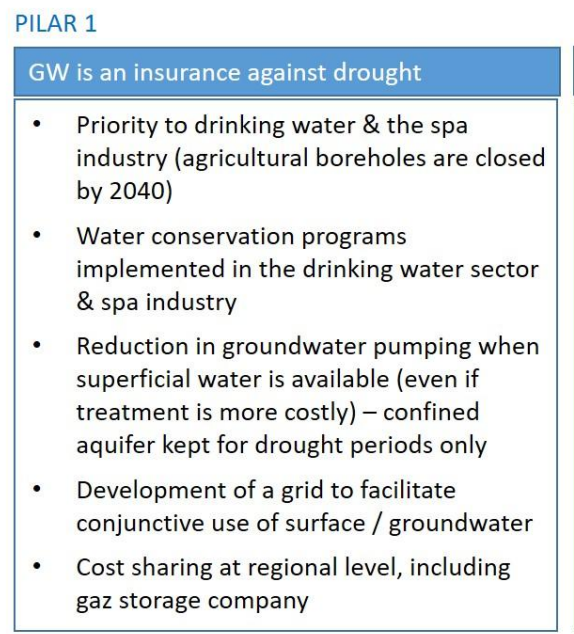

PILAR 2

Definition of sustainable extraction

- Groundwater threshold target set for 2070

- Maximum groundwater level decline agreed (in $\mathrm{cm}$ / year), with use restrictions if target not met

- Extraction limit defined in volume (per year), based on modelling
PILAR 3

Protection of water quality

- Protection zones are defined in emergence areas; restrictions in terms of pesticide use

- Groundwater threshold levels are defined; pumping is restricted if those levels are breached

- Extraction limits are set as annual volume for each protection zone / each well

- New agricultural wells authorized if no use of pesticides

The third step involved a third workshop aimed to generate discussions on the institutional set-up that could be used to support the implementation of a collaborative governance. Three main institutional frames were presented and discussed (Table 2). The workshop involved participants from Step 2 and as well as other actors who could not participate in the previous workshops but decided to participate in the following workshops. A pre-workshop was also organised with local politicians to give them an overview of the project and its outcomes following the first two sets of workshops.

\section{Table 2. Proposed institutional set-ups}

\begin{tabular}{|l|l|}
\hline Name & Description \\
\hline Charter & $\begin{array}{l}\text { Voluntary commitment to implement good practices in terms of water use } \\
\text { efficiency, data sharing, transparency on extractions }\end{array}$ \\
\hline Contract & $\begin{array}{l}\text { Voluntary participation to a programme of actions (corresponding to the } \\
\text { three pillars presented in Figure 4), with public subsidies }\end{array}$ \\
\hline $\begin{array}{l}\text { Water } \\
\text { Management } \\
\text { Plan }\end{array}$ & $\begin{array}{l}\text { Establishment of a Water Commission in charge of developing a legally } \\
\text { binding groundwater management pans }\end{array}$ \\
\hline
\end{tabular}

The workshops involved a mix of presentations from the project team, discussion rounds (including systematic roundtable to ensure all participants could express their opinion) and responding to short questionnaires to collect additional written evidence from all participants on a number of key issues. It is important to note that the project was funded in the context of a wider research initiative aiming at understanding the complex hydrogeology of the region. The project team facilitating the workshops consisted of an interdisciplinary team of scientists working for the French Geological Survey. It was clear to participants that the scope of the project was exploratory. 
Although the methodology was designed for a progressive consideration of issues (from an understanding of the current situation, the consequences of laisser-faire and potential responses), local actors often discussed elements of all three issues in all workshops. Therefore, it was decided to present the results of the participatory processes according to five outcomes, presented below.

\subsection{Developing a shared representation of the resource and its uses}

Most participants were representative of groundwater users (agriculture, spa industry, public water supply, see Table 1) and came to the workshops bringing their own mental model or conceptual representation of the groundwater resources. These mental models were based on local knowledge related to the operation of boreholes (direct observations, site-specific studies). Users were aware of the existence of the aquifer, its depth, productivity, the quality of water contained in the deep layers and the existence of a declining trend in water levels. However, only a few participants could fit this local knowledge into a more general representation of the aquifer system. The workshops were therefore useful for all users to understand the larger picture, including the spatial extension of the aquifers, the existence of water flows between different layers and the interdependences between water users.

Local knowledge provided by users was clearly perceived as complementary to the scientific information provided by the project team, which contributed to the collective appropriation of the information and the emergence of a shared representation of the groundwater resources. Lay participants, such as elected politicians, who came without pre-existing groundwater mental models, adopted the conceptual representation of the aquifer proposed by the research team, probably because it was in line with the local knowledge of the other (more technical) participants.

The identification of groundwater management issues was also consensual, given that users participating to the workshops could provide first hand evidence of the problems caused by groundwater depletion or quality deterioration, confirming data provided by the research team.

Overall, several factors have contributed to the relatively rapid emergence of a shared vision of the deep groundwater resources, uses and management issues. First, the project team was considered as scientifically legitimate, as several experts involved were in charge of a research program on deep confined aquifers at the regional level. Second, technical and scientific experts from other institutions were invited, who could potentially contradict or complement the information provided by the project team. Third, local stakeholders could contribute to the discussion by bringing local knowledge. Importantly, the project team was transparent about sources of uncertainties, in particular related to groundwater recharge and interactions between aquifer layers.

\subsection{Raising awareness of the benefits of collective action}

One of the main objectives of the workshops was to raise awareness among stakeholders of the risks of inaction. This was achieved during Workshop 2 through the discussion of the laisser-faire scenario describing the potential consequences of a lack of integrated groundwater management at the 2050 horizon. Overall, participants considered the laisser-faire scenario realistic. Several participants even considered that the situation depicted in the narrative description would probably occur much earlier. A questionnaire filled out during Workshop 3 helped further identify assumptions that were considered more or less credible than others (Figure 5 ). 


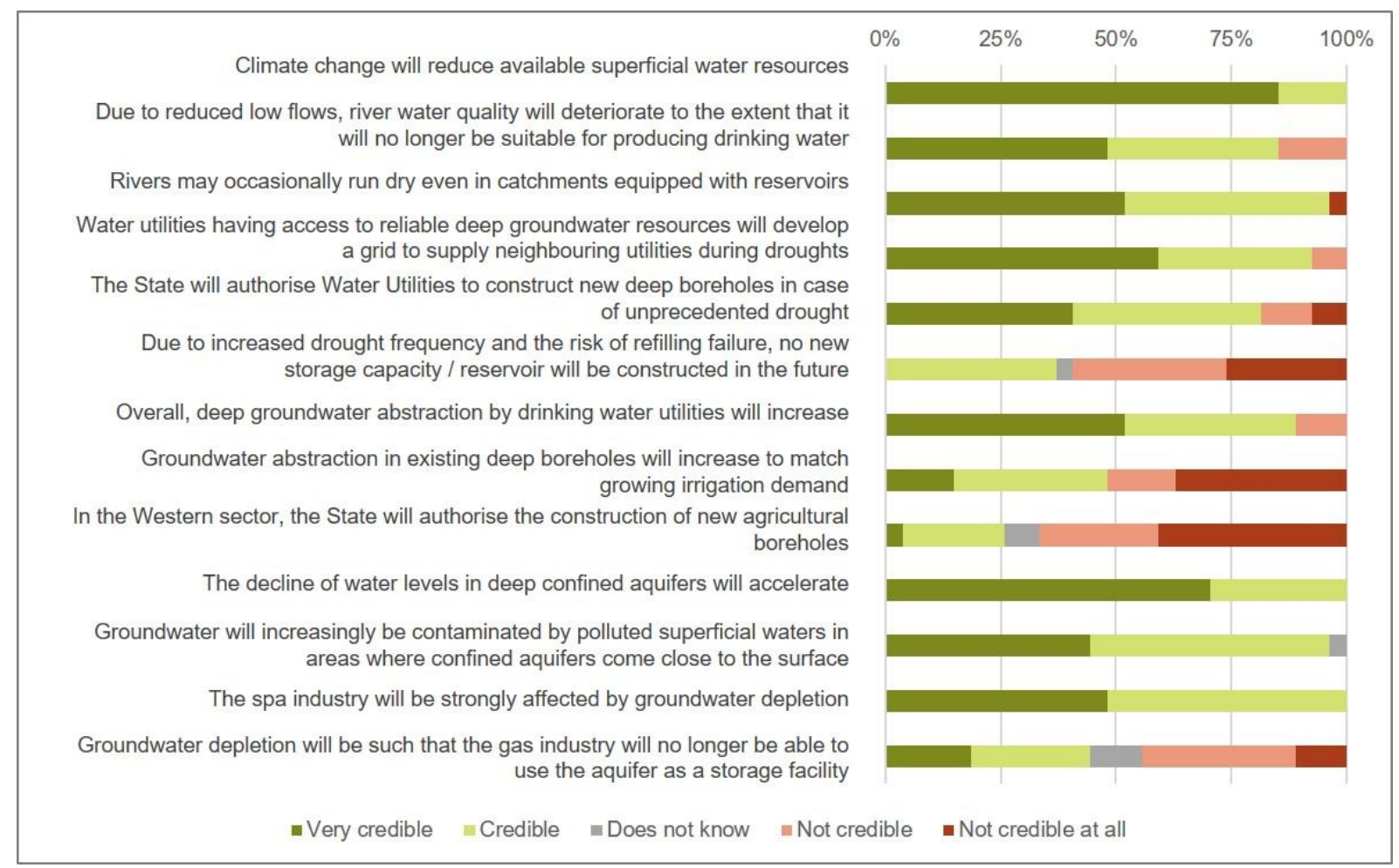

Fig. 5. Perception of the main assumptions formulated in the narrative description of the laisser-faire scenario (Workshop 2, $N=27$ respondents)

Discussions helped construct a first representation of the causal link between driving factors likely to accentuate groundwater depletion and the consequences of the deterioration of the resource. Most driving factors included in the narrative were confirmed and illustrated. For instance, several actors gave precise examples of urban areas which were already contemplating the possibility of drilling new boreholes to secure their water supply, currently dependent on fragile surface resources.

A limited number of assumptions were also questioned or contested during discussions. For instance, many participants, in particular agricultural representatives, refused to take for granted the assumption that no new surface water reservoirs could be constructed in the future. They asked for scientific evidence of a key assumption made in the narrative scenario, i.e. that those reservoirs could not be filled under future climate conditions.

Given the general credibility of the laisser-faire scenario and some of its key assumptions, a consensus emerged on the need to take action to prevent this laisser-faire scenario from happening. There was clearly a shared understanding that significant costs could be avoided, benefiting to all users.

\subsection{Defining management principles and operational actions}

The next result obtained was the definition of objectives that would guide the definition of concrete groundwater management measures. There was a clear consensus among participants that the 
resource should be protected from depletion and pollution in order to ensure its possible use for future generations. The fact that the pristine water contained in deep confined aquifers is several thousand years old contributed to this consensus because the resource was considered as a natural heritage to be used wisely. The identification of such shared ethical and philosophical values appear important to create shared foundations for future collective action.

Users agreed on several key management principles during Workshop 3 (Figure 6). First, they agreed on the need to define measurable management objectives, such as for instance extraction limits (in volume) and the definition of groundwater threshold levels that should not be breached. Second, all agreed that water from the aquifers should be used for drinking water supply as a priority and, to a lesser extent, by the spa industry, considering its economic importance at regional level. Uses that do not require a high quality water should be reduced, and if possible satisfied with other sources. This applies primarily to agricultural uses, and implies shutting down and substituting agricultural boreholes where other water resources are available (or reducing irrigation). This substitution principle should also apply to some urban uses, such as the watering of green spaces or fire hydrants, where technically and financially feasible. Third, losses in distribution networks should be reduced and water use efficiency improved (e.g. households' per capita consumption, water saving technologies in commercial, industrial and institutional uses).

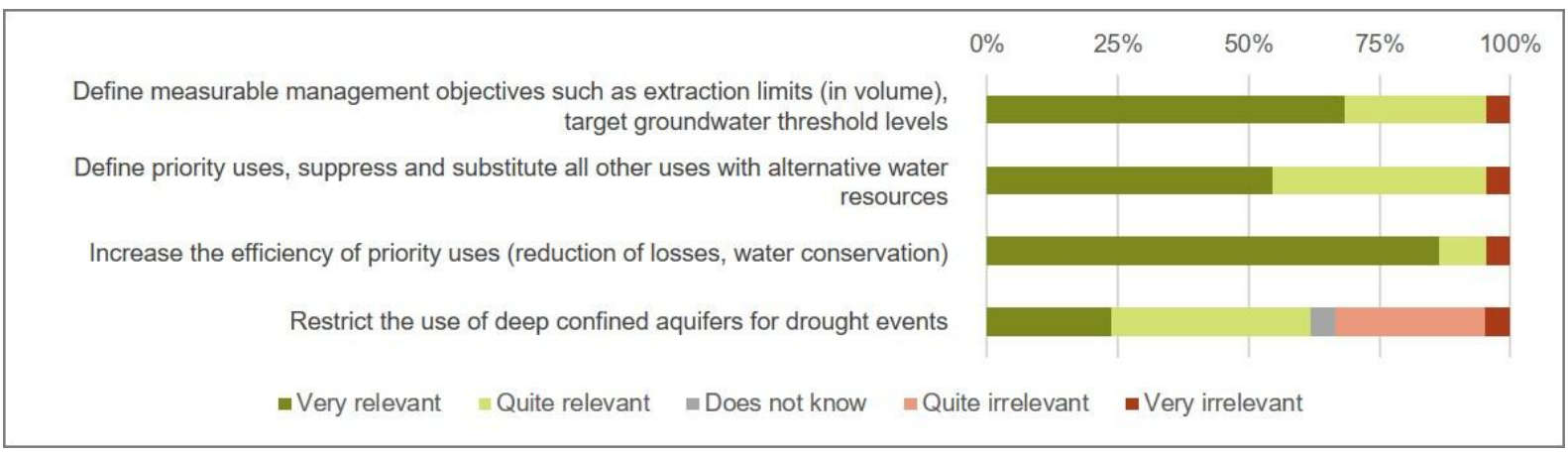

Fig. 6. Evaluation of proposed management principles for managing dropping water levels in the SMS aquifer by workshop participants (Workshop 3, N=22 respondents)

The emergence of a consensus on those principles was somewhat surprising because their implementation would imply significant efforts and costs to some stakeholders. Some users, for instance farmers, could have claimed their legitimacy to continue using water based on seniority in use. Farmers' representatives nevertheless agreed that such high quality (and old) water should not be used to irrigate crops.

The authors observed two points that moderate the consensus found on management principles. First, although farmers agreed on the priorities that should apply to uses extracting water from the deep aquifers, they were against any extraction ban unless alternative sources of supply were developed. However, alternative sources of water are not readily available today. Developing new reservoirs is not always possible because of stringent regulatory, environmental, socio-political and 
economic constraints. Second, diverse views were expressed concerning the proposal to restrict the use of the aquifers only to periods of drought, when alternative resources are scarce, as this would require extensive reorganisation for users and infrastructure (grid) who are currently depending on this resource. Both observations indicate that, while users can find common management principles, issues of cost allocation remain central (Girard et al 2016).

Furthermore, moving from management principles to measurable objectives was not possible. A number of formulations were proposed as a starting point for the discussion on management objectives. Alternative formulations relating to groundwater-level objectives included for example: (i) ensure a stabilisation of groundwater at current piezometric levels; (ii) ensure that groundwater levels do not decline by more than 0.5 meter per year; (iii) ensure that the piezometric surface remains above the critical level that is required for underground gas storage. Formulations relating to abstraction-level objectives were also suggested: (i) setting a fixed annual cap for total water abstraction from the deep aquifers; (ii) setting an average cap that can be exceeded if needed during a particularly dry year, provided that the 5-year average remains below cap. Such measurable objectives could be set for different time horizons or for different areas. However, participants considered that there was a lack of scientific information to discuss those proposals. Participants expressed the need for using a groundwater model to choose between these different formulations, based on simulation results. In particular, participants stressed the need to evaluate the maximum volume that should be abstracted to stabilize water levels. Clearly, more knowledge was needed to characterize the relationship between extraction and the evolution of groundwater level over time.

Although measurable management objectives could not immediately be defined, participants agreed that a number of no-regret actions could be initiated while waiting for additional knowledge. It consists of all actions that will be necessary and useful whatever the precise definition of measurable management objectives: all water saving actions and actions to reduce the risk of contamination of deep aquifers. Most of the discussions focussed on how the financial burden should be shared. The dominant opinion was that all users of water resources of the aquifers and overland surface water bodies should contribute, whether or not they currently used the deep aquifers. Indeed, the participants agreed that it would not be fair to impose the cost of the protection of the aquifers only to their current users, since the resource represents an asset for all future inhabitants of the area. There was little contradictory opinion expressed in the room, possibly because participants were mainly users of these aquifers.

\subsection{Mapping governance options}

One of the outcomes of the workshop was the identification of a number of general governance principles. First, users agreed that they should collectively act and that the regional level (including the whole study area) was the appropriate scale due to the interdependency between existing and potential users of the deep aquifers, and those of surface water resources. Second, there is a need to develop a groundwater management plan specifying mid-term objectives ( 5 years) as well as a set of operational actions. Third, users believed that the State should supervise that process in order to ensure commitment from various stakeholders and to guarantee that management actions are consistent, efficient and based on a fair distribution of effort.

Four institutional instruments were proposed and discussed by stakeholders during the last workshop. Their characteristics are briefly described in Table 3. Overall, there was agreement that, in the short term, an initial commitment to collective action could be made more concrete via the signature of a "memorandum of understanding", which is currently being adopted (see section 
'Evaluation of outcomes'). This would provide a first political impetus to give direction and a common agenda to practitioners. In the medium term, contractual instruments together with funding could be used to encourage collaboration. In the longer term, the deep aquifers would benefit from a common and more ambitious management plan that would coordinate more systematically management actions by individual actors.

Table 3. Main characteristics of the four institutional set-ups proposed to workshop participants

\begin{tabular}{|c|c|c|c|c|}
\hline Institutional set up & $\begin{array}{l}\text { Charter of good } \\
\text { practice }\end{array}$ & $\begin{array}{l}\text { Aquifer } \\
\text { contract }\end{array}$ & $\begin{array}{l}\text { Territorial } \\
\text { project }\end{array}$ & $\begin{array}{c}\text { Integrated } \\
\text { Management Plan }\end{array}$ \\
\hline Objective & $\begin{array}{c}\text { Signal } \\
\text { commitment to } \\
\text { act by signatories } \\
\text { and define action } \\
\text { principles }\end{array}$ & $\begin{array}{l}\text { Fund a } \\
\text { program } \\
\text { of work }\end{array}$ & $\begin{array}{l}\text { Define a water } \\
\text { allocation plan } \\
\& \text { long-term } \\
\text { vision of water } \\
\text { use }\end{array}$ & $\begin{array}{l}\text { Design a long legally } \\
\text { binding long-term } \\
\text { plan }\end{array}$ \\
\hline \multicolumn{5}{|l|}{ Content } \\
\hline - $\quad$ Deals with issues related to: & $\begin{array}{l}\text { Specific to } \\
\text { charter }\end{array}$ & $\begin{array}{l}\text { Specific to } \\
\text { contract }\end{array}$ & $\begin{array}{l}\text { Quantity } \\
\text { (mainly) }\end{array}$ & $\begin{array}{c}\text { All water } \\
\text { management issues }\end{array}$ \\
\hline $\begin{array}{l}\text { - Performs a diagnosis of the } \\
\text { situation }\end{array}$ & No & Yes & Yes & Yes \\
\hline - $\quad$ Funds operational actions & No & Yes & Yes & Yes \\
\hline $\begin{array}{l}\text { - Defines legally binding } \\
\text { objectives (e.g. sustainable } \\
\text { extraction limits) }\end{array}$ & No & No & Partially & Yes \\
\hline $\begin{array}{l}\text { - Provides a long term vision of } \\
\text { water management }\end{array}$ & No & No & No & Yes \\
\hline \multicolumn{5}{|l|}{ Stakeholders involved } \\
\hline - $\quad$ Funding agencies & No & Yes & Yes & Yes \\
\hline - $\quad$ Regulatory Agencies & No & No & Yes & Yes \\
\hline - $\quad$ River / aquifer managers & Yes & Yes & Yes & Yes \\
\hline - Water users' representatives & Yes & No & Yes & Yes \\
\hline Life cycle & $\begin{array}{l}\text { No duration, one } \\
\text { shot }\end{array}$ & $\begin{array}{l}3 \text { years, } \\
\text { one shot }\end{array}$ & $\begin{array}{l}5 \text { years, one } \\
\text { shot }\end{array}$ & $\begin{array}{l}\text { 5-10 years, updated } \\
\text { regularly }\end{array}$ \\
\hline
\end{tabular}

523

\subsection{Evaluation of outcomes}

An evaluation survey was filled out by participants at the end of the last workshop. $91 \%$ of participants indicated that the participatory process advanced their own thinking (Figure 7). A majority (68\%) also stated that the process succeeded in building a common representation of the aquifer systems and in creating a favourable ground to move to the implementation phase.

Furthermore, the collective dynamic initiated by the approach did not stop at the end of the last workshop. Stakeholders are currently making their commitment to collective action more concretely via the signature of a "Charter of commitment for the governance and concerted, sustainable and solidary management of the deep aquifers of the Adour basin". By June 2021, this charter had been 
signed by 16 members, including the Water Agency and other water management authorities, governments at regional, county (Départements) and local (Communautés de communes) level, Chambre d'Agriculture des Landes, several public water utilities, the gas storage company, and a spa company ; the signature process was underway for several other signatories. The Charter explicitly references and follows on from the participatory approach and its first objective is stated as "to formalize the commitment of stakeholders to continue the dynamic initiated since 2018". By signing the charter, members commit to participate in the governance and reflections on the management of the deep aquifers, with the aim of putting in place a more formal management set-up, and to start implementing adapted policies and no-regret actions (in particular water savings and water quality preservation).

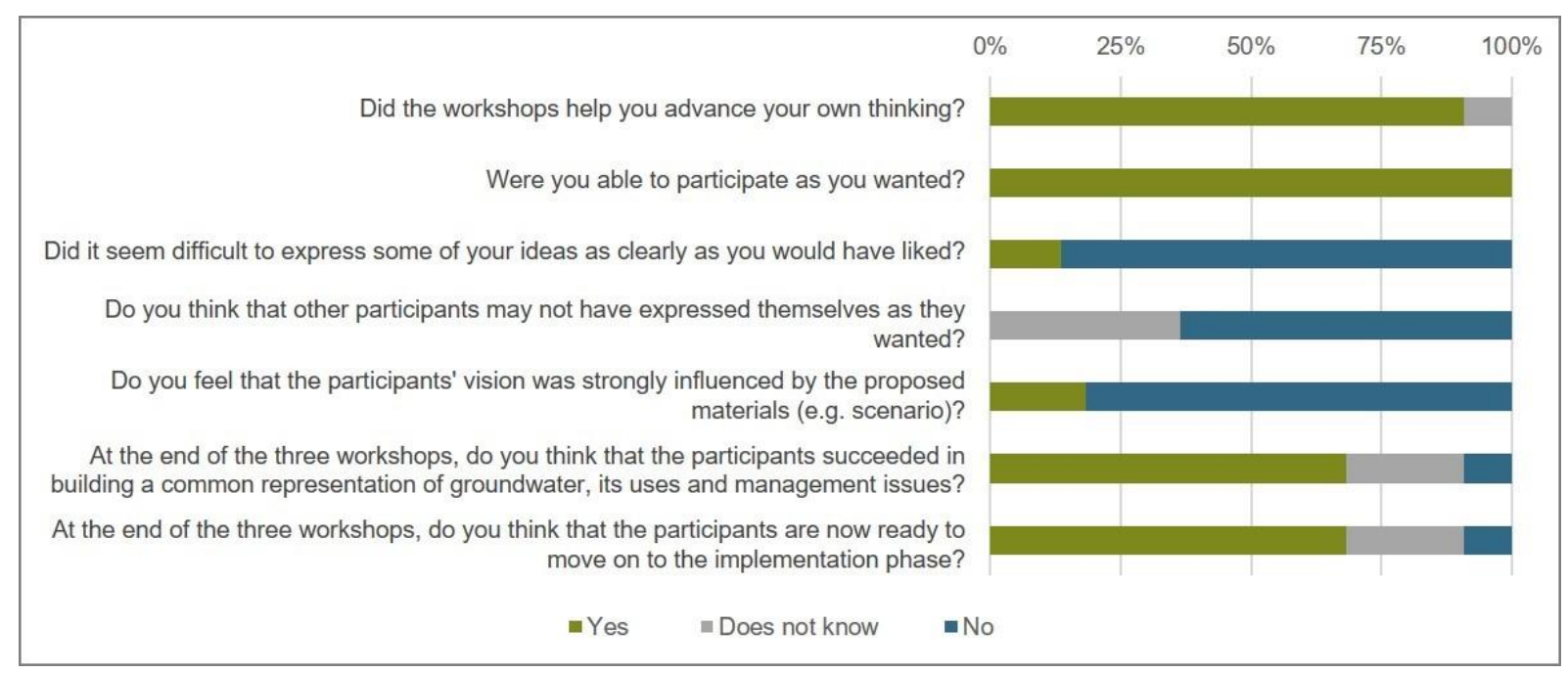

Fig. 7. Evaluation of the methodology and its outcome by participants (Workshop $3, N=22$ respondents)

\section{Discussion}

The paper presented a methodological approach to initiate collective action for the management of a deep, large and confined aquifer, and tested it in the context of an intensively exploited aquifer of France. France has well-established institutions for the management of river basins (Jager et al 2016) and a strong regulatory context for groundwater protection thanks to the EU Water Framework Directive goals to achieve good quantitative and chemical status in all European groundwater bodies. However, as elsewhere in the world, the fate of confined and deep aquifers has often been overlooked, and a lack of interest and engagement from stakeholders and users hindered the needed momentum and political will to implement integrated groundwater management (Rinaudo 2020). The objective of this research was thus to test whether and how participatory scenario analysis and future thinking could generate awareness and a commitment to initiate collective action for the integrated management of a regional, deep and confined aquifer.

Overall, results indicate that participatory scenario analysis has helped generate two ingredients for collective action: improving actors' understanding of their interdependence and the benefits in taking collective action (Ostrom 1990). The methodology has improved some of the main challenges 
when raising stakeholder's awareness of groundwater issues: making them more "visible" (LopezGunn 2009) and enhancing actors' ability to think systematically or holistically on their integrated management (Johnson et al. 2012). Opinions expressed during the final roundtables and the final survey (see section 'Evaluation of outcomes') suggest a greater understanding of the complex and multiple interactions between extraction activities and pollution pressures across the region. In addition, the methodology has increased awareness of the cost of inaction and improved the perception by users of the severity of the problem. These factors are commonly identified as catalysts for collective action (e.g. Lubell et al 2002; Rica et al 2012).

There is also evidence that transformative knowledge was created (Schneider and Rist 2013). During workshops, actors identified a number of implementable measures and expressed the willingness to commit to more collective management of the aquifers during the workshops. Since then, key public actors and stakeholders are in the process of signing the charter of commitment for the sustainable and integrated management of the deep aquifers. These outcomes are not tangible environmental improvements and do not present a specific programme of action, arguably two desirable outcomes of participatory processes (e.g. Newig et al 2018). Yet, the objective set out by the project (i.e. to initiate collective action) was met, with, importantly, concrete commitments made at a political level to engage in further groundwater management planning, when no attention or interest to the issue was shown previous to the workshops.

What are the key features of the methodology that may explain these positive outcomes, and when should it be used for wider implementation? Three key dimensions are discussed here: 1) how the methodology approached stakeholder fatigue, 2) how it integrated local knowledge, and 3) how it made groundwater more "visible".

First, French water management relies already heavily on collaborative work (eg. for catchment planning, river basin management, development of climate change adaptation plan, etc.), while the number of water actors is small. Moreover, many key individual actors from local government are simultaneously solicited by many other public policy participatory design processes. Hence, stakeholder fatigue is a significant challenge in French water management. In participatory scenario approaches, a trade-off exists between asking participants to react to pre-defined scenarios or asking them to co-create scenarios. Scenarios may be co-created to reduce expert bias in scenario development and adequately integrate stakeholder knowledge, views and preferences (Schneider and Rist 2013). However, such level of co-creation requires significant involvement from stakeholders, as each variable must be defined, weighted and integrated into coherent narratives. This increases the risk of stakeholder fatigue.

The methodology presented in this paper thus opted for participatory scenario analysis, structured around a rapid appraisal through one-to-one interviews and short workshops where participants discuss a small number of pre-defined scenarios. The positive outcomes of the study support the conclusion of Reed al (2018) who rejected the "normative assertions that engagement should always be as far up the ladder as possible, to use Arnstein's ladder analogy" and, instead, argued that "all types of engagement should be available to use", based on the "understanding of what works" (according to the analogy of a "wheel of participation"). In this case study, participatory scenario analysis proved to be efficient in exploring the complexity of the system, the drivers determining its evolution, possible transformations and their consequences, as well as the levers for action. It gave meaning to engage in further participation and build a commitment for further collective action on managing the deep aquifers. 
Second, mixing scientific and local knowledge is a recommendation found in much research on participatory processes (e.g. Blackmore 2007; Reed et al 2008; 2018; Simpson and De Loe 2019). In this research, the integration of local knowledge was an essential element of the approach taken by the scientific team. The development of the regional aquifer model relied on data, results and hydrogeological models from public authorities and stakeholders. The preparation of scenarios relied equally on general statistics as on information provided by, and views from, these local actors. This approach resulted in a more robust and shared understanding of the social-ecological system.

In addition, the scenarios were developed to "match the representation of stakeholder interests and decision-making power to the spatial scale of the issues being considered" (Reed et al. 2018). A stepwise process was adopted, first by involving key technicians and practitioners working at county or regional level for public authorities and user groups. This allowed providing a more shared understanding at a technical level when moving to the political arena by involving elected representatives from county and regional authorities and user groups. This stepwise approach to supporting changes in environmental management is coherent with lessons learned from policy studies examining paradigmatic policy change, for instance in flood risk management (Johnson et al. 2005) or river basin management (Huitema et al 2014).

Third, to address the issue of making groundwater "visible", much time was spent on the visual representations of the geology of the aquifers, and finding the right analogies and local examples to explain hydrogeological dynamics. The hydrogeologists involved in the project had a pivotal role in workshops in explaining the underpinning science, in particular to politicians who initially expressed reluctance in engaging in the participatory process by fear of lacking the scientific background. The presentation of the scenarios and their possible consequences through concrete illustrations was a critical step. It was particularly valuable to draw on the interviews to make the scenarios most relevant to the local context. The time spent in communicating scientific knowledge proved essential to generate the level of shared understanding and commitment needed for further collective action.

Overall, the design features that contributed to its success in initiating collective action with respect to the deep aquifers also limit the broader applicability of the methodology. Indeed, the methodology limited on purpose the number and type of participants to those with responsibilities over the management of the deep aquifers (e.g. public authorities) and those with most economic interest in their exploitation. Furthermore, it limited the time spent on workshops. Hence, it does not aim to include all possible viewpoints and interests on the management of the aquifers and it does not aim to create the full range of possible scenario for their management. More formal, comprehensive and inclusive processes would be needed to ensure the robustness and acceptability of the final operational goals, targets and measures of an integrated plan of the deep aquifers. Thus, the methodology is valuable for its role in building a shared understanding of the need for an integrated management of the deep and confined aquifers, and the justification for initiating collection action at a technical and political level.

\section{6}

\section{Conclusion}

With rapid environmental change and a growing groundwater crisis, mobilising actors in reversing declining water levels and pollution of aquifers is an urgent task in many regions of the world. Work on effective tools and methods to initiate and strengthen collective action are thus essential in any attempts to reach sustainability. In particular, there is a need to further develop socio-hydrogeology (Sivapalan et al 2011) and integrate social sciences into the assessment and management of groundwater resources (Barthel et al 2017). This paper shows that participatory scenario analysis can 
make deep, confined aquifers more "visible" to societal actors and contribute to create a shared understanding of the need to adopt more integrated management. The study also shows that participatory scenario analysis can be enough to generate a commitment for collective action on their management, mitigating the issues of stakeholder fatigue that deliberative democracy can create. Overall, the method presented in this paper provides an original contribution to the field of socio-hydrogeology, by combining the integration of social and hydrogeological perspectives into participatory scenario analysis for the management of deep and confined aquifers.

\section{Acknowledgement}

We would like to thank Nicolas Pédron and Arnaud Wuilleumier for contribution to the workshops.

\section{Funding Information and Conflict of Interest}

This research benefited from funding of : the BRGM; the Institution Adour, the Water Agency AdourGaronne; the EU H2020 RURECO project (grant agreement 750553) and French National Agency (INCLUSIVE project, grant number ANR-21-SOIL-0004-02). On behalf of all authors, the corresponding author states that there is no conflict of interest.

\section{References}

Arthurs LA, Elwonger JM (2018) Mental models of groundwater residence: A deeper understanding of students' preconceptions as a resource for teaching and learning about groundwater and aquifers. Journal of Astronomy \& Earth Sciences Education (Jaese), 5(1), 53-66.

Aureli A, Fried J, Martin-Bordes JL, Puri S, Stephan RM (2008) Education and training for transboundary groundwater management as an instrument of dialogue and communication. In Overexploitation and contamination of shared groundwater resources (pp. 25-31). Springer, Dordrecht.

Baldwin C, Tan PL, White I, Hoverman S, Burry K (2012) How scientific knowledge informs community understanding of groundwater. Journal of Hydrology, 474, 74-83.

Blomquist W (1992) Dividing the waters: governing groundwater in Southern California. ICS Press Institute for Contemporary Studies.

BRGM (2021) http://sigesaqi.brgm.fr/Rapports-GAIA.html. Accessed 13 October 2021.

Budds, J (2009). Contested H2O: Science, policy and politics in water resources management in Chile. Geoforum, 40(3), 418-430.

Dickerson DL, Penick JE, Dawkins KR, Van Sickle M (2007) Groundwater in science education. Journal of Science Teacher Education, 18(1), 45-61.

Douez O (2007) Réponse d'un système aquifère multicouche aux variations paléoclimatiques et aux sollicitations anthropiques : approche par modélisation couplée hydrodynamique, thermique et géochimique. (Response of a multi-layered aquifer to paleoclimatic variations and anthropogenic pressures). PhD dissertation in Science and Technology - Water Sciences. 
Duda AM (2018) Leadership and political will for groundwater governance: indispensable for meeting the new Sustainable Development Goals (SDGs). In Villholt et al (eds) Adv. Groundw. Gov., CRC Press, pp. 99-117

Famiglietti JS (2014) The global groundwater crisis. Nature Clim Change 4(11):945, doi:10.1038/nclimate2425

Girard C, Rinaudo JD, Pulido-Velazquez, M (2016) Sharing the cost of river basin adaptation portfolios to climate change: Insights from social justice and cooperative game theory. Water Resour. Res. 52(10):7945-7962, doi/10.1002/2016WR018757

Foster S, Chilton J (2018) Groundwater management: policy principles \& planning practices. In Villholth et al (eds) Advances in groundwater governance, CRC Press, pp. 73-95.

Hérivaux C, Rinaudo JD (2016) Pourquoi et comment préserver les eaux souterraines pour leur rôle d'assurance ? Tour d'horizon de l'expérience française. (why and how to preserve groundwater for their insurance role ? An overview of the French experience). Rapport final. BRGM/RP-65631-FR, 60p.

Institution Adour (2021). https://www.institution-adour.fr/nappes-profondes.html. Accessed 13 October 2021

Jakeman A, Barreteau O, Hunt RJ, Rinaudo JD, Ross A (eds) (2016) Integrated Groundwater Management: Concepts, Approaches and Challenges. Springer, London. ISBN 978-3-319-23576-9

Johnson KA, Dana G, Jordan NR, Draeger KJ, Kapuscinski A, Olabisi LKS, Reich PB (2012) Using participatory scenarios to stimulate social learning for collaborative sustainable development. Ecol. Soc. 17(2), http://dx.doi.org/10.5751/ES-04780-170209

Jouvenel H (2004) Invitation à la prospective (Invitation to foresight). Futuribles, Paris. 87p.

LaDue ND, Ackerman JR, Blaum D, Shipley TF (2021) Assessing Water Literacy: Undergraduate Student Conceptions of Groundwater and Surface Water Flow. Water 13(5), 622.

Lapuyade F, Saltel M, de Grissac B (2020) Setting Sustainable Abstraction Limits in Confined Aquifers: Example from Deep Confined Aquifers in the Bordeaux Region, France. In Rinaudo et al (eds) Sustainable Groundwater Management: a comparative analysis of French and Australian policies and implication to other countries (pp. 229-251). Springer, Cham.

López-Gunn E (2009) Making groundwater institutionally visible. In: Garrido A, Llamas R (ed) Water Policy in Spain. Taylor \& Francis, London. https://doi.org/10.1201/9780203866023

López-Gunn E (2012) Groundwater governance and social capital. Geoforum 43(6):1140-1151, https://doi.org/10.1016/j.geoforum.2012.06.013

Margat J, Van der Gun J (2013) Groundwater around the world: a geographic synopsis. Crc Press.

McClurg S, Sudman RS (2002) Public and stakeholder education to improve groundwater management. In Llamas and Custodio (ds) Intensive Use of Groundwater: Challenges and Opportunities, pp. 276-77. Balkema Publishers

Neverre N, Rinaudo JD, Rouillard J (2020) Les nappes profondes du bassin de l'Adour : état des connaissances relatives aux ressources et aux usages (The deep aquifers of the Adour). Brgm, Nouvelle Ressource en Eau Orleans, France. 

Review of the current state of knowledge and progress towards sustainable development and management. Journal of Hydrology: Regional Studies, 20, 21-34.

Ostrom E (1990) Governing the commons: The evolution of institutions for collective action. Cambridge University Press, Cambridge.

Re V, Misstear B (2018) Education and capacity development for groundwater resources management. In Villholt et al (eds) Advances in groundwater governance, CRC Press, pp. 215-230.

Reed MS, Kenter J, Bonn A, Broad K, Burt TP, Fazey IR, Fraser EDG, Hubacek K, Nainggolan D, Quinn $\mathrm{CH}$, Stringer LC, Ravera F (2013) Participatory scenario development for environmental management: a methodological framework illustrated with experience from the UK uplands. J. Environ. Manage. 128:345-362, https://doi.org/10.1016/j.jenvman.2013.05.016

Rica M, López-Gunn E, Llamas R (2012) Analysis of the emergence and evolution of collective action: An empirical case of Spanish groundwater user associations. Irrig. Drain., 61, 115-125, https://doi.org/10.1002/ird.1663

Richard-Ferroudji A, Lassaube G (2020) The Challenge of making groundwater visible: A review of communication approaches and tools in France. In: Rinaudo JD, Holley C, Montginoul M, Barnett $S$ (eds) Sustainable groundwater management: a comparative analysis of French and Australian policy and implications to other countries. Springer. DOI: 10.1007/978-3-030-32766-8

Richter A, Sieber A, Siebert J, Miczajka-Rußmann V, Zabel J, Ziegler D, Frigerio D (2019). Storytelling for narrative approaches in citizen science: Towards a generalized model. J. Sci. Commun, 18(6), A02.

Rinaudo JD, Montginoul M, Varanda M, Bento S (2012) Envisioning innovative groundwater regulation policies through scenario workshops in France and Portugal. Irrig. Drain. 61:65-74, https://doi.org/10.1002/ird.1661

Rinaudo JD, Maton L, Terrason I, Chazot S, Richard-Ferroudji A, Caballero Y (2013) Combining scenario workshops with modeling to assess future irrigation water demands. Agric. Water Manag 130:103-112, https://doi.org/10.1016/j.agwat.2013.08.016

Rinaudo JD, Marchet P, Billault P (2020) Groundwater management planning at the river basin district level: comparative analysis of the Adour-Garonne and Loire-Bretagne river basins. In Rinaudo et al (eds) Sustainable Groundwater Management: a comparative analysis of French and Australian policies and implication to other countries (pp. 67-91). Springer, Cham.

Robertson J (2020) Challenges in sustainably managing groundwater in the Australian Great Artesian Basin: lessons from current and historic legislative regimes. Hydrogeology Journal, 28(1), 343-360.

Sindico F, Hirata R, Manganelli A (2018) The Guarani Aquifer System: From a Beacon of hope to a question mark in the governance of transboundary aquifers. Journal of Hydrology: Regional Studies, 20, 49-59.

Schneider F, Rist S (2014) Envisioning sustainable water futures in a transdisciplinary learning process: combining normative, explorative, and participatory scenario approaches. Sustain sci 9(4):463-481, https://doi.org/10.1007/s11625-013-0232-6

Skurray JH (2015) The scope for collective action in a large groundwater basin: An institutional analysis of aquifer governance in Western Australia. Ecol Econ 114:128-140, https://doi.org/10.1016/j.ecolecon.2014.12.015 
771 Sivapalan M, Savenije HH, Blöschl G (2012) Socio-hydrology: A new science of people and water.

772 Hydrol. Process, 26(8), 1270-1276.

773 Suvedi M, Krueger D, Shrestha A, Bettinghouse, D. (2000) Michigan citizens' knowledge and 774 perceptions about groundwater. The Journal of Environmental Education, 31(2), 16-21.

775 Terrega (2021). https://www.terega.fr/nos-activites/stockage-de-gaz. Accessed 13 October 2021

776 Van der Heijden K, Bradfield R, Burt G, Cairns, G, Wright G (2002) The sixth sense: Accelerating 777 organizational learning with scenarios. John Wiley \& Sons.

778 Wuilleumier A, Douez, O Pedron N, André L, Serrano, O, Lasseur E, Saplairoles M (2019) 779 Compréhension de la circulation des eaux souterraines dans un système aquifère profond : 780 investigations récentes et valorisation de 100 ans de connaissances et d'études des fluides dans le 781 sud du Bassin aquitain. Géologues n²02, pp. 37-42 